\title{
Analysis of signalized intersection performance using IHCM 1997 method and PTV Vistro software
}

\author{
Budi Yulianto $^{1, *}$, Setiono ${ }^{1}$, Adventaras Bani Setiawan ${ }^{1}$, Dyan Radite Wijaya Putra ${ }^{1}$ \\ Civil Engineering Department, Engineering Faculty, Sebelas Maret University, J1. Ir. Sutami 36A, \\ Surakarta (57126), Indonesia
}

\begin{abstract}
Brigjend Slamet Riyadi road is the main city road serving the traffic of Surakarta City. It is located in the Central Business District so that many vehicles pass through this road. The relatively high traffic volume in Brigjend Slamet Riyadi affects the signalized intersections performance along this road. This study analyses the performance of signalized intersections along the Brigjend Slamet Riyadi road by using the IHCM 1997 method and PTV Vistro software. The IHCM 1997 method is a traffic modelling method based on empirical Indonesian traffic conditions. PTV Vistro is traffic modelling software based on empirical United States America traffic conditions. Analysis of the signalized intersections performance results using both approaches is compared with the field data. Calibration and validation of models is carried out to see the similarity of traffic performance results between models with field data. In general, the IHCM 1997 method produces vehicle queue length closer to field data than the PTV Vistro software. The IHCM 1997 method tends to produce lower degree of saturation, vehicle delay and level of service than the PTV Vistro software.
\end{abstract}

\section{Background}

Junctions are critical elements in a highway transport system as they are the locus points where delay, accidents and emissions tend to be concentrated [1]. One of the junction types which cater for increasing levels of traffic flows is the traffic signal control junction. Traffic movement on the intersection is set by the signal timing. Optimization of the signal timing affects the intersection performance which determines degree of saturation, vehicle queue length, vehicle delay and level of service (LOS) intersection.

Knowing the signalized intersection performance requires traffic modelling. The standard traffic modelling in Indonesia to calculate signalized intersection performance is the Indonesian Highway Capacity Manual (IHCM) 1997 method [2]. The IHCM 1997 method is a traffic modelling method based on empirical Indonesian traffic conditions. Several commercial traffic modelling commonly used to calculate signalized intersection performance include TRANSYT, OSCADY, PTV Vistro [3-5]. PTV Vistro is a traffic software developed by PTV Germany to analyse traffic performance of roads and intersections. In analysing signalized intersection performance, PTV Vistro software uses

\footnotetext{
* Corresponding author: budi.yulianto@ft.uns.ac.id
} 
several methods, one of which Highway Capacity Manual (HCM) 2010 method [6]. The HCM 2010 method is a traffic modelling method based on empirical United States America traffic conditions. This study is conducted to determine the differences between IHCM 1997 and PTV Vistro models results, with field data using default and calibrated values of traffic parameters. Furthermore, it carried out a comparison of analytical results between PTV Vistro software using the HCM 2010 approach with the IHCM 1997 method for analysis of signalized intersections.

Brigjend Slamet Riyadi road, as the main city road serving the population movement of Surakarta City, is used as a case study. It is located in the Central Business District so that many vehicles pass through this road. The relatively high traffic volume in Brigjend Slamet Riyadi road affects the signalized intersections performance along this road. In this study, the performance of signalized intersections along the Brigjend Slamet Riyadi road is analysed using the IHCM 1997 method and PTV Vistro software with several scenarios. The calibration and validation process is carried out to find out the similarity of the models' results with the field data. Calibrated traffic parameters include the value of the base saturation flow and passenger car units (PCU) for motorcycles [4,7]. Traffic measures of performance used as comparison is vehicle queue length. In the end of the analysis, the result of the signalized intersection performance in the form of degree of saturation, vehicle queue length, vehicle delay and LOS intersection of calibrated and validated models of the IHCM 1997 method and PTV Vistro software are compared.

\section{Research methods}

\subsection{Location of research}

The objects of the research are Purwosari Intersection, Gedengan Intersection, Sriwedari Intersection, Ngapeman Intersection, Pasar Pon Intersection and Nonongan Intersection which are located along the Brigjend Slamet Riyadi road in Surakarta City as shown in Figure 1. All intersections are controlled by traffic signals. Table 1 shows the stage and green split arrangement of each intersection.

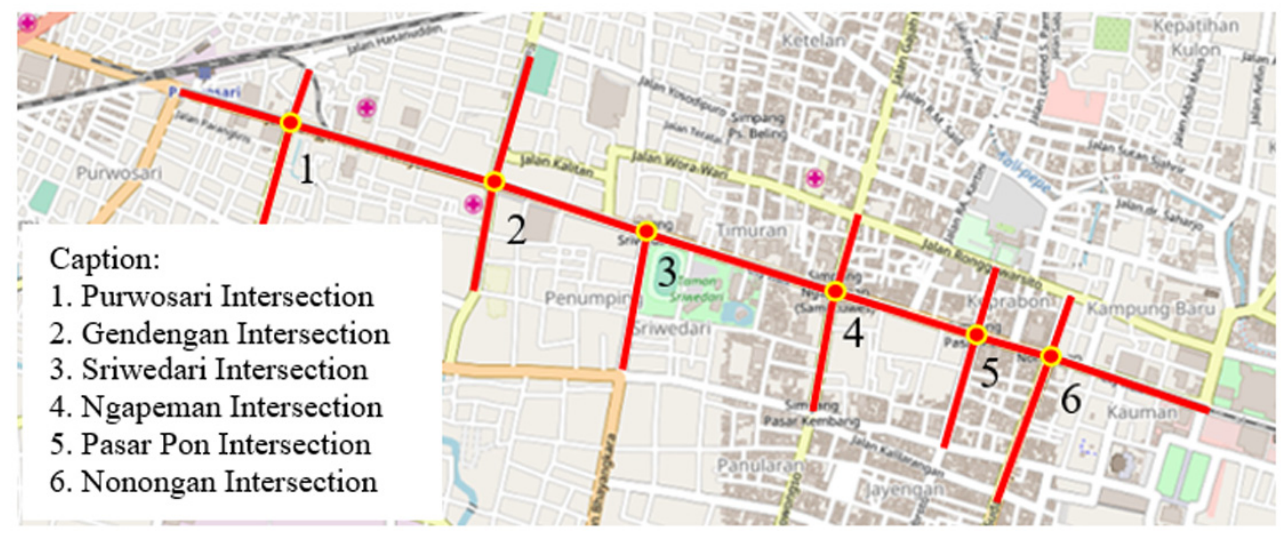

Fig. 1. Map of intersection locations. 
Table 1. Stage and green split arrangement of each intersection.

\begin{tabular}{|c|c|c|c|c|c|c|c|}
\hline Intersection & Stage & $\begin{array}{l}\text { Green } \\
\text { Time } \\
\text { (sec) }\end{array}$ & $\begin{array}{l}\text { Cycle } \\
\text { Time } \\
\text { (sec) }\end{array}$ & Intersection & Stage & $\begin{array}{l}\text { Green } \\
\text { Time } \\
\text { (sec) }\end{array}$ & $\begin{array}{l}\text { Cycle } \\
\text { Time } \\
\text { (sec) }\end{array}$ \\
\hline \multirow{3}{*}{ Purwosari } & West & $30(35)$ & \multirow{3}{*}{$\begin{array}{c}74 * \\
(80)^{+}\end{array}$} & \multirow{2}{*}{ Ngapeman } & West & $40(40)$ & \multirow{2}{*}{$82(90)$} \\
\hline & East & $10(10)$ & & & North & $32(42)$ & \\
\hline & North-South & $19(20)$ & & \multirow{2}{*}{ Pasar Pon } & West & $25(30)$ & \multirow{2}{*}{$65(67)$} \\
\hline \multirow{3}{*}{ Gendengan } & West & $28(34)$ & \multirow{3}{*}{$\begin{array}{c}91 \\
(103)\end{array}$} & & South & $30(27)$ & \\
\hline & North & $24(30)$ & & \multirow{3}{*}{ Nonongan } & West & $40(40)$ & \multirow{3}{*}{97 (97) } \\
\hline & South & $24(24)$ & & & South & $15(17)$ & \\
\hline Sriwedari & West & $22(31)$ & $48(56)$ & & North & $26(25)$ & \\
\hline
\end{tabular}

\subsection{Stages of research}

Stages in the implementation of research can be explained as follows:

1. Primary and secondary data collection for performing signalized intersection performance. Required data includes traffic volume, composition and turning proportions, vehicle speed, geometry, signal timing, and traffic measures of performance (i.e. vehicle queue length), population, land use, and transportation system in Surakarta City. Primary data such as traffic volume, signal timing and vehicle queue length data are collected at each intersection during morning and afternoon peak hours namely 06:3007:30 am and 04:00-05.00 pm, respectively.

2. Data analysis and signalized intersection performance calculation. The results of data analysis are used to calculate signalized intersection performance using the IHCM 1997 method and PV Vistro software. Signalized intersections performance calculation is divided into 3 scenarios namely: a) base model, use default values; b) calibration 1 model, change the value of base saturation flow based on research result [4]; c) calibration 2 model, change the value of base saturation flow and PCU for motorcycle based on research result [7]. The differences of base saturation flow and PCU value of each scenario can be seen in Table 2 .

Table 2. The differences of base saturation flow and PCU value of each scenario.

\begin{tabular}{|c|c|c|}
\hline Scenarios & IHCM 1997 Method & PTV Vistro Software \\
\hline Base Model & PCU of Motorcycle $=0.2$ & PCU of Motorcycle $=0.2$ \\
(BM) & S0 = approach width x 600 & S0 $=1,900$ \\
\hline $\begin{array}{c}\text { Calibration 1 Model } \\
(\mathrm{C} 1 \mathrm{M})\end{array}$ & PCU of Motorcycle $=0.2$ & PCU of Motorcycle $=0.2$ \\
\hline S0 $=$ approach width $\times 775$ & S0 $=$ lane width $\times 775$ \\
\hline Calibration 2 Model & PCU of Motorcycle $=0.15$ & PCU of Motorcycle $=0.15$ \\
$(\mathrm{C} 2 \mathrm{M})$ & S0 $=$ approach width $\times 775$ & S0 = lane width $\times 775$ \\
\hline
\end{tabular}

3. Comparison of signalized intersection performance results of the IHCM 1997 method, PTV Vistro software and field data. Vehicle queue length results for all scenarios of the IHCM 1997 method and PTV Vistro software are compared to the field data. Signalized intersection performance result of the IHCM 1997 method and PV Vistro software scenario that produces vehicle queue length closest to the field data are compared in terms of degree of saturation, vehicle queue length, vehicle delay and LOS intersection.

4. Conclusion. Drawing conclusions from the results of research conducted. 


\section{Results and discussions}

\subsection{Comparison of signalized intersection performance results of the IHCM1997 method and field data}

Comparison of the IHCM 1997 method results and field data for morning and afternoon peak hour conditions can be seen on Table 3 and 4. The calculation results show that the base model (BM) produces a relatively large degree of saturation value. The vehicle queue length produced is very long and not in accordance with the reality in the field, especially for the approach that has high degree of saturation flow value $(>0.8)$. The greater degree of saturation flow tends to produce the greater percentage difference in the vehicle queue length between the model results and field data. This phenomenon indicates that the IHCM 1997 method with default values produces traffic measure of performance that does not match the field conditions, especially on traffic conditions which is close to the unstable conditions $(\geq$ $0.8=\operatorname{LOS} \mathrm{D})$.

Table 3. Comparison of IHCM 1997 method results and field data (morning peak hour).

\begin{tabular}{|c|c|c|c|c|c|c|c|c|c|}
\hline \multirow[b]{2}{*}{ Intersection } & \multirow[b]{2}{*}{ Approach } & \multicolumn{3}{|c|}{ Degree of Saturation } & \multicolumn{4}{|c|}{ Vehicle Queue Length (meter) } & \multirow{2}{*}{$\begin{array}{c}\% \\
\text { (BM- } \\
\text { FD) }\end{array}$} \\
\hline & & $\mathbf{B M}$ & C1M & C2M & BM & C1M & C2M & $\begin{array}{l}\text { Field } \\
\text { Data } \\
\text { (FD) }\end{array}$ & \\
\hline \multirow{2}{*}{ Purwosari } & North & 0.82 & 0.64 & 0.54 & 94 & 79 & 67 & 32 & $193 \%$ \\
\hline & West & 1.06 & 0.82 & 0.73 & 333 & 121 & 102 & 76 & $341 \%$ \\
\hline \multirow{3}{*}{ Gendengan } & West & 1.05 & 0.81 & 0.74 & 254 & 115 & 101 & 96 & $166 \%$ \\
\hline & South & 1.21 & 0.93 & 0.83 & 551 & 157 & 121 & 100 & $451 \%$ \\
\hline & North & 0.90 & 0.70 & 0.53 & 133 & 104 & 77 & 70 & $91 \%$ \\
\hline \multirow{2}{*}{ Sriwedari } & West & 0.87 & 0.68 & 0.61 & 84 & 69 & 60 & 60 & $41 \%$ \\
\hline & South & 0.44 & 0.34 & 0.29 & 38 & 37 & 33 & 41 & $8 \%$ \\
\hline \multirow{2}{*}{ Ngapeman } & West & 1.04 & 0.80 & 0.75 & 201 & 93 & 84 & 45 & $347 \%$ \\
\hline & North & 0.74 & 0.57 & 0.51 & 90 & 78 & 67 & 91 & $1 \%$ \\
\hline \multirow{2}{*}{ Pasar Pon } & West & 0.62 & 0.48 & 0.43 & 53 & 50 & 43 & 42 & $26 \%$ \\
\hline & South & 0.51 & 0.40 & 0.35 & 62 & 59 & 51 & 32 & $95 \%$ \\
\hline \multirow{3}{*}{ Nonongan } & West & 0.82 & 0.64 & 0.57 & 121 & 107 & 93 & 72 & $68 \%$ \\
\hline & North & 0.31 & 0.24 & 0.31 & 28 & 27 & 24 & 37 & $25 \%$ \\
\hline & South & 0.40 & 0.31 & 0.26 & 46 & 46 & 39 & 55 & $15 \%$ \\
\hline
\end{tabular}


Table 4. Comparison of IHCM 1997 method results and field data (afternoon peak hour).

\begin{tabular}{|c|c|c|c|c|c|c|c|c|c|}
\hline \multirow{3}{*}{ Intersection } & & \multicolumn{2}{|c|}{ Degree of Saturation } & \multicolumn{2}{|c|}{ Vehicle Queue Length (meter) } & \% \\
\cline { 3 - 11 } & Approach & $\mathbf{B M}$ & $\mathbf{C 1 M}$ & $\mathbf{C 2 M}$ & $\mathbf{B M}$ & $\mathbf{C 1 M}$ & $\mathbf{C 2 M}$ & $\begin{array}{c}\text { Field } \\
\text { Data } \\
\text { (FD) }\end{array}$ & $\begin{array}{c}\text { (BM- } \\
\text { FD) }\end{array}$ \\
\hline \multirow{2}{*}{ Purwosari } & North & 0.93 & 0.72 & 0.64 & 132 & 95 & 83 & 45 & $193 \%$ \\
\hline & West & 0.69 & 0.54 & 0.48 & 86 & 77 & 68 & 77 & $11 \%$ \\
\hline \multirow{3}{*}{ Gendengan } & West & 0.79 & 0.60 & 0.55 & 104 & 93 & 83 & 98 & $5 \%$ \\
\cline { 2 - 11 } & South & 1.10 & 0.85 & 0.76 & 327 & 130 & 109 & 82 & $298 \%$ \\
\cline { 2 - 11 } & North & 0.67 & 0.52 & 0.39 & 96 & 88 & 70 & 28 & $241 \%$ \\
\hline \multirow{2}{*}{ Sriwedari } & West & 0.66 & 0.51 & 0.47 & 68 & 60 & 53 & 50 & $36 \%$ \\
\hline \multirow{2}{*}{ Ngapeman } & South & 0.56 & 0.44 & 0.39 & 47 & 45 & 41 & 39 & $23 \%$ \\
\hline \multirow{2}{*}{ Pasar Pon } & West & 0.96 & 0.74 & 0.67 & 133 & 100 & 87 & 47 & $183 \%$ \\
\cline { 2 - 11 } & North & 1.04 & 0.80 & 0.72 & 291 & 133 & 112 & 97 & $200 \%$ \\
\cline { 2 - 11 } & West & 0.50 & 0.38 & 0.34 & 45 & 42 & 37 & 48 & $6 \%$ \\
\hline \multirow{3}{*}{ Nonongan } & South & 0.57 & 0.44 & 0.38 & 68 & 64 & 56 & 30 & $126 \%$ \\
\cline { 2 - 10 } & West & 0.74 & 0.57 & 0.51 & 106 & 96 & 83 & 73 & $45 \%$ \\
\cline { 2 - 10 } & North & 0.28 & 0.22 & 0.18 & 25 & 24 & 22 & 32 & $23 \%$ \\
\hline
\end{tabular}

Calibration and validation processes indicate that the change in the value of base saturation flow constant from 600 to 775 [4] still yields a relatively large vehicle queue length value compared to field data $(\mathrm{C} 1 \mathrm{M})$. By changing the value of PCU for motorcycles from 0.2 to 0.15 [7] then the vehicle queue length value produced by the $\mathrm{C} 2 \mathrm{M}$ becomes closer to the field data. The $t$ test results show Sig values $>0.025$, meaning that the difference between the C2M results with the field data is not significant in the morning and afternoon peak hour conditions (see Table 5).

Table 5. The $t$ test results between IHCM 1997 method and field data.

\begin{tabular}{|c|c|c|c|c|c|c|c|c|}
\hline \multirow{3}{*}{ Time } & \multicolumn{5}{|c|}{ Paired Differences } & \multirow{3}{*}{$\mathbf{t}$} & \multirow{3}{*}{ df } & \multirow{3}{*}{$\begin{array}{l}\text { Sig. } \\
(2- \\
\text { tailed) }\end{array}$} \\
\hline & \multirow[t]{2}{*}{ Mean } & \multirow[t]{2}{*}{$\begin{array}{c}\text { Std. } \\
\text { Deviation }\end{array}$} & \multirow[t]{2}{*}{$\begin{array}{l}\text { Std. Error } \\
\text { Mean }\end{array}$} & \multicolumn{2}{|c|}{$\begin{array}{l}\text { 95\% Confidence } \\
\text { Interval of the } \\
\text { Difference } \\
\end{array}$} & & & \\
\hline & & & & Lower & Upper & & & \\
\hline $\begin{array}{c}\text { Morning Peak } \\
\text { Hour } \\
\end{array}$ & 8.19286 & 19.50741 & 5.21358 & -3.07039 & 19.45610 & 1.571 & 13 & 0.140 \\
\hline $\begin{array}{l}\text { Afternoon } \\
\text { Peak Hour }\end{array}$ & $1.13643 \mathrm{E} 1$ & 19.95328 & 5.33274 & -0.15639 & 22.88496 & 2.131 & 13 & 0.053 \\
\hline
\end{tabular}

\subsection{Comparison of signalized intersection performance results of PTV Vistro software and field data}

Comparison of PTV Vistro software results and field data for morning and afternoon peak hour conditions can be seen in Table 6 and 7. The calculation results show that the base model (BM) produces a relatively large degree of saturation value, as well as the vehicle queue length. The PTV Vistro software results in general are similar to that of the IHCM 1997 method. The greater degree of saturation tends to produce the greater percentage difference in the vehicle queue length between the model results and field data. 
Table 6. Comparison of PTV Vistro software results and field data (morning peak hour).

\begin{tabular}{|c|c|c|c|c|c|c|c|c|c|}
\hline \multirow[b]{2}{*}{ Intersection } & \multirow[b]{2}{*}{ Approach } & \multicolumn{3}{|c|}{ Degree of Saturation } & \multicolumn{4}{|c|}{ Vehicle Queue Length (meter) } & \multirow{2}{*}{$\begin{array}{c}\% \\
\text { (BM- } \\
\text { FD) }\end{array}$} \\
\hline & & $\mathbf{B M}$ & C1M & C2M & $\mathbf{B M}$ & C1M & C2M & $\begin{array}{l}\text { Field } \\
\text { Data } \\
\text { (FD) }\end{array}$ & \\
\hline \multirow{2}{*}{ Purwosari } & North & 0.79 & 0.64 & 0.55 & 86 & 75 & 63 & 32 & $170 \%$ \\
\hline & West & 1.26 & 0.89 & 0.79 & 979 & 168 & 136 & 76 & $1,197 \%$ \\
\hline \multirow{3}{*}{ Gendengan } & West & 1.25 & 0.92 & 0.83 & 748 & 188 & 157 & 96 & $682 \%$ \\
\hline & South & 1.06 & 1.04 & 0.92 & 293 & 263 & 145 & 100 & $193 \%$ \\
\hline & North & 0.86 & 0.71 & 3 & 122 & 101 & 75 & 70 & $74 \%$ \\
\hline \multirow{2}{*}{ Sriwedari } & West & 0.86 & 0.63 & 0.51 & 95 & 63 & 53 & 60 & $58 \%$ \\
\hline & South & 0.56 & 0.46 & 0.35 & 39 & 35 & 28 & 41 & $5 \%$ \\
\hline \multirow{2}{*}{ Ngapeman } & West & 0.77 & 0.54 & 0.51 & 121 & 98 & 92 & 45 & $169 \%$ \\
\hline & North & 0.55 & 0.55 & 0.48 & 74 & 74 & 65 & 91 & $19 \%$ \\
\hline \multirow{2}{*}{ Pasar Pon } & West & 0.67 & 0.47 & 0.41 & 72 & 63 & 58 & 42 & $71 \%$ \\
\hline & South & 0.67 & 0.47 & 0.38 & 80 & 69 & 56 & 32 & $149 \%$ \\
\hline \multirow{3}{*}{ Nonongan } & West & 0.98 & 0.69 & 0.50 & 197 & 133 & 104 & 72 & $173 \%$ \\
\hline & North & 0.22 & 0.18 & 0.15 & 25 & 24 & 19 & 37 & $33 \%$ \\
\hline & South & 0.95 & 0.67 & 0.57 & 103 & 73 & 63 & 55 & $88 \%$ \\
\hline
\end{tabular}

Table 7. Comparison of PTV Vistro software results and field data (afternoon peak hour).

\begin{tabular}{|c|c|c|c|c|c|c|c|c|c|}
\hline \multirow[b]{2}{*}{ Intersection } & \multirow[b]{2}{*}{ Approach } & \multicolumn{3}{|c|}{ Degree of Saturation } & \multicolumn{4}{|c|}{ Vehicle Queue Length (meter) } & \multirow{2}{*}{$\begin{array}{c}\% \\
\text { (BM- } \\
\text { FD) }\end{array}$} \\
\hline & & $\mathbf{B M}$ & C1M & C2M & BM & C1M & C2M & $\begin{array}{l}\text { Field } \\
\text { Data } \\
\text { (FD) }\end{array}$ & \\
\hline \multirow{2}{*}{ Purwosari } & North & 0.90 & 0.74 & 0.66 & 121 & 93 & 80 & 45 & $169 \%$ \\
\hline & West & 0.84 & 0.59 & 0.53 & 132 & 103 & 91 & 77 & $71 \%$ \\
\hline \multirow{3}{*}{ Gendengan } & West & 0.92 & 0.67 & 0.62 & 177 & 139 & 125 & 98 & $79 \%$ \\
\hline & South & 1.00 & 0.98 & 0.87 & 196 & 180 & 125 & 82 & $138 \%$ \\
\hline & North & 0.65 & 0.53 & 0.40 & 93 & 86 & 66 & 28 & $230 \%$ \\
\hline \multirow{2}{*}{ Sriwedari } & West & 0.77 & 0.54 & 0.49 & 89 & 69 & 62 & 50 & $79 \%$ \\
\hline & South & 0.64 & 0.52 & 0.47 & 56 & 49 & 43 & 39 & $44 \%$ \\
\hline \multirow{2}{*}{ Ngapeman } & West & 0.92 & 0.64 & 0.58 & 185 & 130 & 114 & 47 & $294 \%$ \\
\hline & North & 0.75 & 0.75 & 0.96 & 122 & 122 & 105 & 97 & $26 \%$ \\
\hline \multirow{2}{*}{ Pasar Pon } & West & 0.58 & 0.45 & 0.39 & 69 & 62 & 54 & 48 & $44 \%$ \\
\hline & South & 0.64 & 0.40 & 0.35 & 69 & 61 & 52 & 30 & $129 \%$ \\
\hline \multirow{3}{*}{ Nonongan } & West & 0.96 & 0.67 & 0.60 & 176 & 129 & 112 & 73 & $142 \%$ \\
\hline & North & 0.19 & 0.15 & 0.13 & 20 & 20 & 16 & 32 & $37 \%$ \\
\hline & South & 0.82 & 0.60 & 0.52 & 79 & 69 & 61 & 38 & $108 \%$ \\
\hline
\end{tabular}

As in the case of the IHCM 1997 method, the calibration and validation processes of C2M results show that by changing the base saturation flow parameters on each lane of the road and the value of PCU for motorcycle from 0.2 to 0.15 the model produces vehicle queue length value closer to the field data. The $t$ test results show the difference between the $\mathrm{C} 2 \mathrm{M}$ model results with the field data is not significant in the morning peak hour condition, while in the afternoon peak condition it is (see Table 8). 
Table 8. The $t$ test results between PTV Vistro software and field data.

\begin{tabular}{|c|c|c|c|c|c|c|c|c|}
\hline \multirow{3}{*}{ Time } & \multicolumn{5}{|c|}{ Paired Differences } & \multirow{3}{*}{$\mathbf{t}$} & \multirow{3}{*}{ df } & \multirow{3}{*}{$\begin{array}{l}\text { Sig. } \\
(2- \\
\text { tailed) }\end{array}$} \\
\hline & \multirow[t]{2}{*}{ Mean } & \multirow[t]{2}{*}{$\begin{array}{c}\text { Std. } \\
\text { Deviation }\end{array}$} & \multirow[t]{2}{*}{$\begin{array}{l}\text { Std. Error } \\
\text { Mean }\end{array}$} & \multicolumn{2}{|c|}{$\begin{array}{l}95 \% \text { Confidence } \\
\text { Interval of the } \\
\text { Difference } \\
\end{array}$} & & & \\
\hline & & & & Lower & Upper & & & \\
\hline $\begin{array}{c}\text { Morning Peak } \\
\text { Hour }\end{array}$ & $1.89786 \mathrm{E} 1$ & 28.75954 & 7.68631 & 2.37331 & 35.58383 & 2.469 & 13 & 0.028 \\
\hline $\begin{array}{l}\text { Afternoon } \\
\text { Peak Hour }\end{array}$ & 2.30429E1 & 20.66758 & 5.52364 & 11.10975 & 34.97596 & 4.172 & 13 & 0.001 \\
\hline
\end{tabular}

\subsection{Comparison of signalized intersection performance results of IHCM1997 method and PTV Vistro software}

Signalized intersection performance results of the IHCM 1997 method and PTV Vistro software scenario that produces vehicle queue length closest to the field data, i.e. C2M are compared in terms of degree of saturation, vehicle queue length, vehicle delay and LOS intersection. Tables 8 and 9 show the comparison of the IHCM 1997 method and PTV Vistro software results for morning and afternoon peak hour conditions. In general, the IHCM 1997 method produces vehicle queue length closer to field data than the PTV Vistro software. Eleven and nine out of fourteen data for morning and afternoon conditions respectively are closer to the field data. The IHCM 1997 method tends to produce lower degree of saturation than the PTV Vistro software. This causes the value of vehicle delay and LOS of the intersection to decrease. The trend of analysis results is similar to those done by [8].

Table 8. Comparison of IHCM 1997 method and PTV Vistro software results (morning peak hour).

\begin{tabular}{|c|c|c|c|c|c|c|c|c|}
\hline \multirow[t]{2}{*}{ Intersection } & \multirow{2}{*}{$\begin{array}{c}\text { Approac } \\
\text { h }\end{array}$} & \multicolumn{2}{|c|}{$\begin{array}{c}\text { Degree of } \\
\text { Saturation }\end{array}$} & \multicolumn{3}{|c|}{$\begin{array}{l}\text { Vehicle Queue Length } \\
\text { (meter) }\end{array}$} & \multicolumn{2}{|c|}{$\begin{array}{c}\text { Vehicle Delay } \\
\text { (sec/pcu) } \\
\text { LOS }\end{array}$} \\
\hline & & $\begin{array}{c}\text { IHCM } \\
1997\end{array}$ & $\begin{array}{c}\text { PTV } \\
\text { Vistro }\end{array}$ & $\begin{array}{c}\text { IHCM } \\
1997\end{array}$ & $\begin{array}{c}\text { PTV } \\
\text { Vistro }\end{array}$ & $\begin{array}{l}\text { Field } \\
\text { Data }\end{array}$ & $\begin{array}{c}\text { IHCM } \\
1997\end{array}$ & $\begin{array}{c}\text { PTV } \\
\text { Vistro }\end{array}$ \\
\hline \multirow{2}{*}{ Purwosari } & North & 0.54 & 0.55 & 67 & 63 & 32 & \multirow{2}{*}{$\begin{array}{r}23.54 \\
\mathrm{C}\end{array}$} & \multirow{2}{*}{$\begin{array}{r}26.17 \\
\mathrm{D}\end{array}$} \\
\hline & West & 0.73 & 0.79 & 102 & 136 & 76 & & \\
\hline \multirow{3}{*}{ Gendengan } & West & 0.74 & 0.83 & 101 & 157 & 96 & \multirow{3}{*}{$\begin{array}{l}35.63 \\
\mathrm{D}\end{array}$} & \multirow{3}{*}{$\begin{array}{r}49.6 \\
\mathrm{E}\end{array}$} \\
\hline & South & 0.83 & 0.92 & 121 & 145 & 100 & & \\
\hline & North & 0.53 & 0.53 & 77 & 75 & 70 & & \\
\hline \multirow{2}{*}{ Sriwedari } & West & 0.61 & 0.51 & 60 & 53 & 60 & \multirow{2}{*}{$\begin{array}{r}13.81 \\
\text { B }\end{array}$} & \multirow{2}{*}{$\begin{array}{r}10.88 \\
\text { B }\end{array}$} \\
\hline & South & 0.29 & 0.35 & 33 & 28 & 41 & & \\
\hline \multirow{2}{*}{ Ngapeman } & West & 0.75 & 0.51 & 84 & 92 & 45 & \multirow{2}{*}{$\begin{array}{r}24.9 \\
\mathrm{C}\end{array}$} & \multirow{2}{*}{$\begin{array}{r}20.35 \\
\mathrm{C}\end{array}$} \\
\hline & North & 0.51 & 0.48 & 67 & 65 & 91 & & \\
\hline \multirow{2}{*}{ Pasar Pon } & West & 0.43 & 0.41 & 43 & 58 & 42 & \multirow{2}{*}{$\begin{array}{r}14.41 \\
\text { B }\end{array}$} & \multirow{2}{*}{$\begin{array}{c}15.55 \\
\mathrm{C}\end{array}$} \\
\hline & South & 0.35 & 0.38 & 51 & 56 & 32 & & \\
\hline \multirow{3}{*}{ Nonongan } & West & 0.57 & 0.50 & 93 & 104 & 72 & \multirow{3}{*}{$\begin{array}{r}23.89 \\
\mathrm{C}\end{array}$} & \multirow{3}{*}{$\begin{array}{r}36.47 \\
\mathrm{D}\end{array}$} \\
\hline & North & 0.31 & 0.15 & 24 & 19 & 37 & & \\
\hline & South & 0.26 & 0.57 & 39 & 63 & 55 & & \\
\hline
\end{tabular}


Table 9. Comparison of IHCM 1997 method and PTV Vistro software results (afternoon peak hour).

\begin{tabular}{|c|c|c|c|c|c|c|c|c|}
\hline \multirow[t]{2}{*}{ Intersection } & \multirow[t]{2}{*}{ Approach } & \multicolumn{2}{|c|}{$\begin{array}{c}\text { Degree of } \\
\text { Saturation }\end{array}$} & \multicolumn{3}{|c|}{$\begin{array}{l}\text { Vehicle Queue Length } \\
\text { (meter) }\end{array}$} & \multicolumn{2}{|c|}{$\begin{array}{c}\text { Vehicle Delay } \\
\text { (sec/pcu) } \\
\text { LOS }\end{array}$} \\
\hline & & $\begin{array}{c}\text { IHCM } \\
1997\end{array}$ & $\begin{array}{c}\text { PTV } \\
\text { Vistro }\end{array}$ & $\begin{array}{c}\text { IHCM } \\
1997\end{array}$ & $\begin{array}{c}\text { PTV } \\
\text { Vistro }\end{array}$ & $\begin{array}{l}\text { Field } \\
\text { Data }\end{array}$ & $\begin{array}{c}\text { IHCM } \\
1997\end{array}$ & $\begin{array}{c}\text { PTV } \\
\text { Vistro }\end{array}$ \\
\hline \multirow{2}{*}{ Purwosari } & North & 0.64 & 0.66 & 83 & 80 & 45 & \multirow{2}{*}{$\begin{array}{c}21.46 \\
\mathrm{C}\end{array}$} & \multirow{2}{*}{$\begin{array}{c}21.21 \\
\mathrm{C}\end{array}$} \\
\hline & West & 0.48 & 0.53 & 68 & 91 & 77 & & \\
\hline \multirow{3}{*}{ Gendengan } & West & 0.55 & 0.62 & 83 & 125 & 98 & \multirow{3}{*}{$\begin{array}{c}35.45 \\
D\end{array}$} & \multirow{3}{*}{$\begin{array}{c}42.65 \\
\mathrm{E}\end{array}$} \\
\hline & South & 0.76 & 0.87 & 109 & 125 & 82 & & \\
\hline & North & 0.39 & 0.40 & 70 & 66 & 28 & & \\
\hline \multirow{2}{*}{ Sriwedari } & West & 0.47 & 0.49 & 53 & 62 & 50 & \multirow{2}{*}{$\begin{array}{c}12.64 \\
\text { B }\end{array}$} & \multirow{2}{*}{$\begin{array}{c}10.25 \\
\mathrm{~B} \\
\end{array}$} \\
\hline & South & 0.3 & 0.47 & 41 & 4 & 39 & & \\
\hline \multirow{2}{*}{ Ngapeman } & West & 0.67 & 0.58 & 87 & 11 & 4 & \multirow{2}{*}{$\begin{array}{r}25.22 \\
D\end{array}$} & \multirow{2}{*}{$\begin{array}{r}26.74 \\
\mathrm{D}\end{array}$} \\
\hline & North & 0.72 & 0.96 & 112 & 105 & 97 & & \\
\hline \multirow{2}{*}{ Pasar Pon } & West & 0.34 & 0.39 & 37 & 54 & 48 & \multirow{2}{*}{$\begin{array}{r}16.57 \\
\mathrm{C}\end{array}$} & \multirow{2}{*}{$\begin{array}{r}15.61 \\
\mathrm{C}\end{array}$} \\
\hline & South & 0.38 & 0.35 & 56 & 52 & 30 & & \\
\hline \multirow{3}{*}{ Nonongan } & West & 0.51 & 0.60 & 83 & 112 & 73 & \multirow{3}{*}{$\begin{array}{r}28.29 \\
D\end{array}$} & \multirow{3}{*}{$\begin{array}{r}32.87 \\
\mathrm{D}\end{array}$} \\
\hline & North & 0.18 & 0.13 & 22 & 16 & 32 & & \\
\hline & South & 0.26 & 0.52 & 40 & 61 & 38 & & \\
\hline
\end{tabular}

The analysis signalised intersection performance using the IHCM 1997 method and PTV Vistro software show differences in results due to some reasons as follows:

- The basic saturation flow parameter used in the calibration and validation processes using the IHCM 1997 method formula. This might not suit the PTV Vistro software approach. This is because the analysis of traffic movement of the IHCM 1997 method is based on the width of the approach, while PTV Vistro software is based on the width of the lane.

- The adjustment factor used in saturation flow calculation between IHCM 1997 method and PTV Vistro software is different.

- The signal timing calculation between the IHCM 1997 method and PTV Vistro software is different.

\section{Conclusion}

The result of the signalized intersections performance analysis indicates that the vehicle queue length output of base model IHCM 1997 and PTV Vistro software is different to that of the vehicle queue length based on field data. It is necessary to calibrate and validate the model. By changing the value of base saturation flow and PCU for motorcycles, the models produce vehicle queue length closer to the field data. $T$ test results show that there is no significant difference between model results and field data, apart from the PTV Vistro software model for afternoon peak hour. The IHCM 1997 method tends to produce lower degree of saturation, vehicle delay and LOS than PTV Vistro software.

The IHCM 1997 method for the current condition often yields an analysis result that is less appropriate to the conditions in the field. Therefore, this manual is updated to adapt to the latest traffic developments of the Indonesia Highway Capacity Guideline (IHCG) 2014 [9]. The use of the IHCG 2014 method as a replacement manual for IHCM 1997 is not yet a requirement. The results of the analysis with the IHCG 2014 method is slightly better than the IHCM 1997 method. However, there is still a need for improvement due to the relatively significant difference of the IHCG 2014 method output with the field data [10]. 


\section{References}

1. The Institution of Highways and Transportation, Transport in The Urban Environment, (1997)

2. Directorate General Bina Marga Indonesia Indonesian, Indonesian Highway Capacity Manual, (1997)

3. D. I. Robertson, TRANSYT: a traffic network study tool, Report LR253, Road Research Laboratory, Ministry of Transport, Crowthorne, Berkshire, (1969)

4. W. Widodo, Perbandingan Antara Metode MKJI (1996) dengan Program OSCADY pada Simpang Bersinyal, Tesis Megister Sistem dan Teknik Transportasi, Universitas Gadjah Mada, Yogyakarta, (1997)

5. PTV AG, PTV Vistro User Manual, Germany PT Group, (2015)

6. TRB, Highway Capacity Manual 2010, Transportation Research Board, Washington, (2010)

7. G. Rahayu, S. Atmaja, and A. Munawar, Analisis Arus Jenuh dan Panjang Antrian pada Simpang Bersinyal: Studi Kasus di Jalan Dr. Sutomo-Suryopranoto Yogyakarta, Jurnal Ilmiah Semesta Teknika. Vol. 12, No.1: 99-108, (2009)

8. S. Sulistyono, W. Kriswardhana, N. N. Hayati, I. Destiyanto, Perbandingan Kinerja Simpang Menggunakan PTV Vistro dan MKJI Pada Kawasan Perkotaan Lumajang, Simposium XIX FSTPT, Universitas Islam Indonesia, 11-13 Oktober, (2016)

9. Ministry of Public Work, Indonesian Highway Capacity Guideline, (2014)

10. S. Budi, G. Sihite, A. K. Indriastuti, Y. Priyono, Perbandingan Kinerja Simpang Bersinyal Berdasarkan PKJI 2014 dan Pengamatan Langsung, Jurnal Karya Teknik Sipil, Vol. 6, No. 2, Universitas Diponegoro, (2017) 